reformer, was the first President of the Republic of Turkey (1923-38). He modernised legal and educational systems in Turkey, and set aside traditional laws which prevented equality between the sexes.

\title{
Mixed Feelings
}

\section{DAVID GARNETT}

From David Garnett, The Familiar Faces: Being Volume Three of the Golden Echo (London: Chatto \& Windus, 1962) pp. 113-14. David Garnett (1892-1981), novelist and critic, made several visits to the Shaws at Whitehall and Ayot in the course of preparing his edition of the letters of T. E. Lawrence (1938). His view of the Shaws may have been coloured by the difficulty he had in persuading Charlotte to release Lawrence's letters to her for publication.

Once I drove over from Hilton ${ }^{1}$ to lunch with them at the vicarage at Welwyn which was their resort in the country. It is a disagreeable late Victorian brick house hidden behind shrubberies - a house the outside of which nothing could make beautiful. But the Shaws had made it as ugly as it is possible to imagine inside as well. It revealed in both of them an absolute absence of any visual taste. In the narrow entrance hall there was a bust of - if my memory is to be trusted - Mr Sidney Webb. In none of the rooms I entered did I notice a single piece of good furniture. Carpets and wallpapers were hideous, mantelpieces and tables crowded with a clutter of souvenirs and bric-à-brac. In Bernard Shaw's workroom pride of place was taken by an enormous photograph of a grey donkey. Charlotte Shaw who was showing me the room told me that it was an enlargement of a snapshot taken by Bernard in the West of Ireland and that he had been much attached to the animal, going out to see it once every day from their hotel in the field where it was pastured. At lunch Shaw talked freely about old friends, such as the Oliviers, ${ }^{2}$ but, as always, in everything he said I detected a curious spiritual itchiness, the uneasiness of a man whose vanity will never allow him to forget himself in the interest of the subject under discussion. Yet he was obviously very kind and good as well as being a cultured gentleman with an Irish accent, who could tell plenty of amusing stories. Indeed he was amusing and charming in describing his affection for the donkey.

\section{NOTES}

1. Garnett lived at Hilton Hall in the village of Hilton, Huntingdonshire.

2. I.e. the Sydney Oliviers (see above, pp. 40-1). 